\title{
Konjenital Glukoz-Galaktoz Malabsorbsiyonu ve Tekrarlayan Sepsis Atakları Olan Yenidoğan Olgusu
}

\author{
A Newborn with Congenital Glucose-Galactose Malabsorption and \\ Recurrent Episodes of Sepsis
}

Serdar Alan, Zarife Kuloğlu*, Ufuk Çakır, Aytaç Yaman*, Begüm Atasay, Aydan Kansu Tanca*, Saadet Arsan

Ankara Üniversitesi Tıp Fakültesi Çocuk Sağlığı ve Hastallkları Anabilim Dalı, Neonatoloji Bilim Dalı, Ankara, Türkiye

*Ankara Üniversitesi Tip Fakültesi Çocuk Sağlı̆ı ve Hastalıkları Anabilim Dalı, Çocuk Gastroenteroloji Bilim Dalı, Ankara, Türkiye

Yazışma Adresi/Address for Correspondence Dr. Serdar Alan, Ankara Üniversitesi Tıp Fakültesi Çocuk Sağlığı ve Hastallkları Anabilim Dall, Neonatoloji Bilim Dall, Ankara, Türkiye GSM.: +905325991259 E-posta: alanserdar@gmail.com

Geliş Tarihi/Received: 11.01.2013 Kabul Tarihi/Accepted: 12.03.2013

(c) Güncel Pediatri Dergisi, Galenos Yayınevi tarafindan basilmıştrir.

(c) The Journal of Current Pediatrics, published by Galenos Publishing.

\begin{abstract}
ÖZET
Konjenital glukoz ve galaktoz malabsorbsiyonu absorbe edilemeyen glukoz ve galaktoz nedeniyle ortaya çıkan kronik osmotik bir ishal durumudur. Burada, yenidoğan döneminde ishal nedeniyle başvuran ve konjenital glukoz ve galaktoz malabsorbsiyonu tanısı alan, takibinde tekrarlayan Candida albicans, Klebsiella pneumoniae ve Enterococcus faecalis etkenleri ile sepsis atakları geçiren fakat altta yatan hücresel ve humoral immün yetmezlik tespit edilmeyen bir olgu sunulmaktadır. Nadir görülen konjenital glukoz ve galaktoz malabsorbsiyonunda, erken tanı ve uygun tedavinin yaşamı tehdit eden komplikasyonların önüne geçebileceği, büyüme ve gelişmenin normal olabileceği bilinmektedir. Konjenital glukoz ve galaktoz malabsorbsiyonu tanısı alıp tekrarlayan fırsatçı mikroorganizmalarla enfeksiyon geçiren literatürde bizim olgumuz dışında yalnızca bir olgu daha tanımlanmaktadır. (Güncel Pediatri 2013; 11: 85-7)
\end{abstract}

Anahtar kelimeler: Yenidoğan, kojenital glukoz ve galaktoz malabsorbsiyonu, ishal, dehidratasyon, tekrarlayan enfeksiyonlar

\section{SUMMARY}

Congenital glucose-galactose malabsorption is a chronic osmotic diarrhea due to defective absorption of glucose and galactose in the intestine. Here, we present a newborn that was admitted to our hospital for neonatal diarrhea and was diagnosed as congenital glucosegalactose malabsorption. He had recurrent sepsis with Candida albicans, Klebsiella pneumoniae and Enterococcus faecalis during follow-up without having any underlying cellular or humoral immune deficiency.Early diagnosis and appropriate treatment of this rare disease can prevent life-threatening complications, and normal growth and development can be achieved. To our knowledge, the present case will be the second glucose-galactose malabsorption case with recurrent infectious due to opportunistic microorganisms after only one similar case in the literature. (Journal of Current Pediatrics 2013; 11: 85-7)

Key words: Newborn, congenital glucose-galactose malabsorption, diarrhea, dehydration, recurrent infectious

\section{Giriş}

Yașamın ilk birkac gününde ishal nadirdir ve konjenital malabsorbtif hastalıkları düşündürmelidir (1). Glukozgalaktoz malabsorbsiyonu (GGM) absorbe edilemeyen glukoz ve galaktozun bağırsak lümeninde birikimi ile oluşan osmotik bir diyaredir. Neonatal başlangıçlı ağır, sulu ve asidik diyare, glukoz veya galaktoz içeren beslenme devam ettikçe ağırlașarak devam eder ve yașamı tehdit eden komplikasyonlara neden olur (2). Burada tekrarlayan, polimikrobial sepsis atakları olan ve konjenital GGM tanısı alan bir olgu sunularak literatür bilgileri ışığında yenidoğanda ishal ayırıcı tanısı tartışımıştır.

\section{Olgu}

Birinci derece kuzen akraba evliliği olan sağlıkı anne ve babanın 3. çocuğu olarak sorunsuz bir hamilelikten sonra, 38,3 haftalık ve $3920 \mathrm{~g}$ olarak, sezaryen ile dünyaya gelen olgu postnatal beşinci günde $12 \mathrm{kez}$ sulu ishali ve $39,5^{\circ} \mathrm{C}$ ateşi olması nedeniyle doğduğu hastaneye başvurmuştu. 0 dönemde yapılan fizik incelemesinde aktivitesinin, emmesinin, deri turgor-tonusunun azaldığı ve vücut ağırlığı kaybının \%18, serum sodyumunun $168 \mathrm{mEq} / \mathrm{l}$, üresinin $95 \mathrm{mg} / \mathrm{dl}$, kreatininin 0,72 mg/dl ve dışıkıda redüktan maddesinin $3+$ olduğu tespit edilmişti. İshal, hipernatremik 
dehidratasyon, prerenal azotemi ve metabolik asidoz tanıları ile yenidoğan yoğun bakım ünitesine yatırılarak intravenöz sıvı desteği uygulanmış ve laktoz intoleransı düşünülerek laktozsuz mama başlanmıştı. Oral beslenmesi artırılınca ishallerinin devam ettiği ve hipernatremik dehidratasyonun yeniden ortaya çıktığının görülmesi üzerine 15 günlükken ünitemize sevk edildi.

Hasta servise kabul edildiğindeki fizik incelemesi normal sınırlarda idi. Oral beslenmesi kesildi, takibinde ishalin düzeldiği görüldü, osmotik ishal olarak değerlendirildi. Almakta olduğu intravenöz ve oral sıvısı 250 cc/kg/ gün'den kademeli olarak $170 \mathrm{cc} / \mathrm{kg} /$ gün'e kadar inildi ve dıșkıda redüktan maddesi $1+$, pH'sı 5 ve bol yağ globulini saptandı. Olguda muhtemel laktoz intoleransı düșünülerek laktozsuz mama ve laktazim bașlandı. Inek sütü protein alerjisine yönelik bakılan spesifik IgE'si negatif olan olgunun dışkı mikroskopisi normal, dışkı kültürü ve viral patojenler (adenovirüs, rotavirüs) negatif saptandı. Postnatal yirminci gününde Candida albicans septisemisi nedeniyle önce flukanozol, 25. gününde ise amfoterisin $B$ tedavileri bașlandı. Yașamının 35. gününde ateş ve akut faz reaktanlarında artış olan hastada lomber ponksiyonda, $380 / \mathrm{mm}^{2}$ hücre görülmesi, periferik kan kültüründe Klebsiella pneumoniae üremesi nedenleriyle önce meropenem ve amikasin bașlandı, aynı üreme kontrol kan kültürlerinde de devam edince siprofloksasin tedaviye eklendi. Takibinde kan kültüründe Enterococcus faecalis üremesi oldu. Bu dönem içerisinde hepatosplenomegali, trombositopeni, anemi, dissemine intravasküler koagülasyon ve enfeksiyona ikincil hemofagositik sendrom gelişen hastaya, trombosit, eritrosit ve taze donmuş plazma destekleri verildi, kolistin antibiyotik tedavilerine eklendi. Kandida septisemisi için yapılan kranial ve abdominal ultrasonografisi, göz dibi muayenesi ve ekokardiyografisi normaldi. Kontrol kan ve beyin omurilik sıvısı kültürlerinde üreme olmadı. Kolistin tedavisi 14 güne tamamlandı. Hastada altta yatan immün yetmezlik açışından bakılan kantitatif immunglobulinler, CH50, lenfosit alt grupları normal bulundu.

Klinik kötüleşme döneminde oral alamayan hastanın ishalinin azaldığı ama anne sütü ile oral laktazim ve laktozsuz mama ile tekrar ishalinin olduğu görüldü ve osmotik ishalin diğer nedenleri açısından olgu tekrar değerlendirildi. Olgunun oral alımının artırıldığı dönemlerde ishal ile birlikte hipernatremik dehidratasyonun tekrarlaması, laktoz intoleransı olmaması, yenidoğan döneminde klinik bulgu vermesi nedenleriyle konjenital GGM düşünülerek tam hidrolize mama kesilip, karbonhidratsı mama (Galactomin-19 ${ }^{\circledR}$, SHS International, Liverpool, United Kingdom) başlandı ve ishalleri düzelince hastada konjenital GGM tanısı doğrulandı. Genel durumu iyi olan hasta
Galactomin $19 \circledast$ mama ile taburcu edildi. Olgunun 6 . ay kontrolünde vücut ağırlığı 8,7 kg (75-90 persentil), boy $75 \mathrm{~cm}$ (97 persentil), baş çevresi 41,5 cm (10 persentil) saptandı ve nörolojik gelişimi yaşıtları ile uyumlu idi, ek gıda olarak meyve püreleri verildi, ishal gözlenmedi.

\section{Tartıșma}

Yenidoğan döneminde başlayan ishal hızlıca yaşamı tehdit eden dehidratasyona ve malnütrisyona yol açabilir. Bu nedenle yenidoğan ishallerinde erken tanı ve zamanında tedavi çok önemlidir (3). Iki-üç haftadan uzun süren ishaller kronik ishal olarak değerlendirilmektedir. Yenidoğan döneminde kronik ishal ayırıcı tanısında; konjenital mikrovillus atrofisi, tufting enteropati, konjenital GGM, otoimmün enteropati, sukraz-izomaltaz eksikliği, inek sütü allerjisi, konjenital kısa bağırsak, IPEX (Immune dysregulation, polyendocrinopathy, enteropathy, X-linked), konjenital laktaz ekikliği, konjenital klorid ve sodyum malabsarbsiyonu, safra asit malabsorbsiyonu ve konjenital enterokinaz eksikliği öncelikle akla getirilmelidir (4).

Konjenital GGM'da, glukoz ve galaktoz absorbsiyonu çok düşük olmasına karşın früktoz absorbsiyonu normaldir (5). Anne sütünde sukroz ve maltoz bulunmazken, bulunan laktoz bağırsak fırçamsı kenar epitelinde bulunan laktaz enzimi ile normal olarak hidrolize edilir ve glukoz ve galaktoz ortaya çıkar. Bağırsak lümeninde emilemediği için biriken bu basit şekerler su çekerek osmotik ishale yol açar. Sindirilmeyen glukoz ve galaktoz kolona geçtiğinde buradaki bakteriler tarafından fermente edilerek kısa zincirli yağ asitleri oluşur ve dışkının asidik ve yağlı olmasına neden olur (5). Etkilenen bebeklerde genellikle yaşamın ilk birkaç günü bașlayan ağır, yaşamı tehdit eden ishal ve hiperosmolar dehidratasyon, metabolik asidoz görülür (1). Görülen ishal osmotiktir ve enteral beslenme kesildiğinde düzelir. Dışkı pH'sı genellikle $<5,3$ ve dışkıda şeker pozitiftir $(1,2)$.

Glukoz ve galaktoz malabsorbsiyonu otozomal resesif geçişli bir hastalıktır (2). Glukoz ve galaktozun ince bağırsak mukozasında emilimini sodyum bağımlı glukoz transporter proteini 1 sağlar. Taşıyıcı protein sodyum glukoz transporter 1 geni (SGLT 1) tarafından kodlanır $(4,6)$. Bu gen 22q13.1 kromozomunda lokalizedir $(2,4)$.

Literatürde bu tanıyı alan yaklaşık 300 vaka tanımlanmıştır. GGM'de kesin tanı dietten glukoz ve galaktozun tamamen çekilmesi ile ishalin düzelmesi ve früktoz emiliminde sorun olmazken glukoz emiliminin bozuk olduğunun gösterilmesi ile konur (1). Günümüz bilgilerine göre, ailede bilinen bir mutasyon yoksa tanı için genetik testler ile doğrulama gerekli görülmemektedir. SGLT1 geninde yaklaşık 46 mutasyon vardır, ayrıca test masraflı ve zaman alıcıdır $(1,2)$. Ayrıca bu hastaların 
intestinal mukozal yapısı bozulmadığından, biyopside normal villus yapısının korunduğu görülmektedir (5). Bizim olgumuzda da tanı klinik gözlemle konulmuştur.

Tedavide asıl olan glukoz ve galaktozun tamamen diyetten eliminasyonunun sağlanmasıdır. Bunun için kullanılan iki çeșit karbonhidratsız mama vardır (RCF ve Galactomin 19®). Bu mamalar karbonhidrat olarak früktoz içermektedir (1). Biz de olgumuzda Galactomin 19® kullandık.

GGM'de prognoz genellikle iyidir. Hastalar çoğunlukla, büyüdükçe az miktarda glukozu tolere edebilirler. Bu hasta grubu için esas endişe, bu özel mamalar ile yüksek protein ve yağlı diyetin uzun vadeli sonuçlarıdır $(1,2)$. Literatürde renal tübüler asidozu içeren renal disfonksiyon ile ilişkili nefrokalsinozis vakaları GGM'li hastalarda bildirilmiș ancak bunun glukozsuz ve galaktozsuz beslenme ile düzeldiği belirtilmiștir (7). Buna karșın El-Nagger ve arkadașları, diyete uymalarına rağmen, persistan hiperkalsemi, nefrokalsinozis ve distal renal tübüler asidozu devam eden iki olgu tanımlamışlardır (8).

Bizim olgumuzun, yaşamın beşinci gününde başlayan ishal, hipernatremik dehidratasyon ve metabolik asidozunun olması, dışkı muyenesinde redüktan madde pozitifliği ve asidik dışkının belirlenmesi, ishalin osmotik karakter göstermesi, laktozsuz mama ve laktazim ile düzelmemesi ve takibinde glukozsuz ve galaktozsuz mama ile semptomların tamamen ortadan kalkması, tipik bir konjenital GGM hastası olduğunu göstermektedir.

Olgumuz, Candida albicans, Klebsiella Pneumoniae ve Enterococcus faecalis ile sepsis ve menenjit atakları geçirmiştir. Literatürde konjenital GGM olgularında bildirilen sepsis atakları incelendiğinde yalnızca Umman'dan yayınlanan rikets ve nefrojenik diabetes insipidus ile komplike olan bir olguda Candida albicans septisemisi ve septik şok bildirilmiştir (3). Çok düşük doğum ağırlıklı $(<1000 \mathrm{~g})$ bebeklerde invaziv kandida enfeksiyonu \%7-20 sıklıkta görülmekte iken doğum ağırlığı >1500 g olan yenidoğanlarda sıklık \%1'in altındadır (9). Olgumuzda altta yatan humoral ve hücresel immün yetmezlik olmadan fırsatçı mikroorganizmalar ile sepsis ataklarının görülmesi, doğumdan hemen sonra bașlayan ishal nedeniyle bağırsakta kommensal floranın oluşamamasına bağlanabilir. Araştırmalarda, trilyonlarca luminal mikroorganizmaya maruz kalan intestinal mukozanın reseptör aracılı, doğuştan gelen immün sistem sinyalizasyonu ile kommensal bakterilere tolerans geliştirip patojenlere karşı ise peptid, sitokin, kemokin ve fagositer hücrelerle korunduğu gösterilmiştir. Mukozada luminal içerik algılanarak bu moleküler düzenlenmenin yapıldığı öne sürülmektedir (10).

Sonuç olarak, yenidoğan döneminde ishal ile başvuran hastalarda hipernatremik dehidratasyon, metabolik asidoz, gaita asiditesi gibi bulgular varlığında nadir bir hastalık olan konjenital GGM'un da akla getirilmesi, bu hastaların erken tanı ve uygun tedaviyi almalarını sağlayarak yaşamı tehdit eden komplikasyonların engellenmesini ve büyüme, gelişmenin normal olmasını sağlayacaktır.

\section{Kaynaklar}

1. Lee WS, Tay CG, Nazrul N, Paed M, Chai PF. A case of neonatal diarrhoea caused by congenital glucose-galactose malabsorption. Med J Malaysia 2009;64:83-5.

2. Wright EM, Martin MG, Turk E. Familial glucose galactose malabsorption and hereditary renal glycosuria. In: Scriver CR, Beaudet AL, Sly WS, Valle D ed(s). The metabolic and molecular bases of inherited diseases, 8th edn. McGraw-Hill, New York, 2001:4891-908.

3. Passariello A, Terrin G, Baldassarre ME, De Curtis M, Paludetto $R$, Berni Canani $R$. Diarrhea in neonatal intensive care unit. World J Gastroenterol 2010;16:2664-8.

4. Bülbül A, Okan F, Bülbül L, Nuhoğlu A. Yenidoğan döneminde glukoz galaktoz malabsorbsiyonu: Iki olgu sunumu. Şeh Tip Bülteni 2008;42:13-6.

5. Abad-Sinden A, Borowitz S, Meyers R, Sutphen J. Nutrition management of congenital glucose-galactose malabsorption: a case study. J Am Diet Assoc 1997;97:1417-21.

6. Lam JT, Martín MG, Turk E, Hirayama BA, Bosshard NU, Steinmann B, et al. Missense mutations in SGLT1 cause glucose-galactose malabsorbtion by trafficking defects. Biochim Biophys Acta 1999;297-303.

7. Soylu OB, Ecevit C, Altinöz S, Oztürk AA, Temizkan AK, Maeda $\mathrm{M}$, et al. Nephrocalcinosis in glucose-galactose malabsorption: nephrocalcinosis and proximal tubular dysfunction in a young infant with a novel mutation of SGLT1. Eur J Pediatr 2008;167:1395-8

8. El-Naggar W, Balfe JW, Barbar M, Taha D. Nephrocalcinosis in glucose-galactose malabsorption, association with renal tubular acidosis. Pediatr Nephrol 2005;20:1336-39.

9. Zaoutis T, Walsh TJ. Antifungal therapy for neonatal candidiasis. Curr Opin Infect Dis 2007;20:592-7.

10. Indrio F, Neu J. The intestinal microbiome of infants and the use of probiotics. Curr Opin Pediatr 2011;23:145-50. 